PERM JOURNAL OF PETROLEUM AND MINING ENGINEERING

ВЕСТНИК ПНИПУ. ГЕОЛОГИЯ. НЕФТЕЕАЗОВОЕ И ГОРНОЕ ДЕЛО

ISSN 2224-9923

Volume/ Toм 16 №3 2017

http://vestnik-pstu.ru/geo/

УДК 622.323:621.313.334

Article / Статья

(C) PNRPU / ПНИПУ, 2017

\title{
BIPHASE MULTI-POLE COMPENSATED ASYNCHRONOUS MOTOR FOR OIL INDUSTRY
}

\author{
Evgeniy F. Belyaev, Pavel N. Tsylev, Irina N. Shchapova
}

Perm National Research Polytechnic University (29 Komsomolskiy av., Perm, 614990, Russian Federation)

\section{ДВУХФАЗНЫЙ МНОГОПОЛЮСНЫЙ КОМПЕНСИРОВАННЫЙ АСИНХРОННЫЙ ДВИГАТЕЛЬ ДЛЯ НЕФТЯНОЙ ПРОМЫШЛЕННОСТИ}

\section{Е.Ф. Беляев, П.Н. Цылев, И.Н. Щапова}

Пермский национальный исследовательский политехнический университет (614990, Россия, г. Пермь, Комсомольский пр., 29)

Received / Получена: 21.06.2017. Accepted / Принята: 27.07.2017. Published / Опубликована: 15.09.2017

\section{Key words:}

low-productive well, plunger electrical drive, biphase

asynchronous motor, internal reactive power compensation, mathematical model of a biphase compensated motor.
Shift of low-productive oil wells into a continuous more optimal operation mode is possible when plunger electrical drive of plunger pumps is equipped with low-speed asynchronous electric motors. Production of such engines has been constrained until today because of the large dimensions and low values of the most important energy indicator such as power coefficient.

It is proposed to use in the plunger drive of plunger pumps a biphase low-speed compensated asynchronous motor of an original design. A motor has no phase-shifting elements. A magnetic field in an air gap has circular shape in the slip range from 1 to 0 .

Reduction of the number of phases of the stator winding from 3 to 2 allows to reduce dimensions of the engine in 1.5 times. Internal compensation of magnetizing currents of network windings of a motor provides an increase in a power coefficient to almost 1 .

A mathematical model of a biphase low-speed compensated asynchronous motor is developed. A model is based on the magnetic field equation and the Kirchhoff's equation for two network and two compensated stator windings. A sequence of solution of the equations and calculation of a vector magnetic potential and performance characteristics of a biphase lowspeed compensated asynchronous motor are described.

Technical data and results of simulation of a prototype of a biphase compensated asynchronous motor, on whose stator the winding is located, are presented. Its currents excite 10 pairs of poles. An analysis of obtained results confirms the possibility and expediency of development and mass implementation in the oil industry of highly economical energy efficient biphase compensated low-speed asynchronous motors.

\section{Ключевые слова:} низкопродуктивная скважина, электропривод плунжера, двухфазный асинхронный двигатель, внутренняя компенсация реактивной мощности, математическая модель двухфазного компенсированного двигателя.
Перевод низкопродуктивных нефтяных скважин в непрерывный, более оптимальный, режим эксплуатации возможен при применении для электропривода плунжера плунжерных насосов тихоходных асинхронных электрических двигателей. Производство таких двигателей до настоящего времени сдерживается из-за больших габаритов и низких значений важнейшего энергетического показателя - коэффициента мощности.

Предлагается использование для привода плунжера плунжерных насосов оригинальной конструкции двухфазного тихоходного компенсированного асинхронного двигателя, в которой отсутствуют фазосмещающие элементы, а магнитное поле в воздушном зазоре имеет круговую форму в диапазоне скольжений от 1 до 0.

Уменьшение числа фаз обмотки статора с трех до двух позволяет в 1,5 раза уменьшить габариты двигателя, а осуществление внутренней компенсации намагничивающих токов сетевых обмоток двигателя обеспечивает увеличение коэффициента мощности практически до единицы.

Разработана математическая модель двухфазного тихоходного компенсированного асинхронного двигателя, в основу которой положено уравнение магнитного поля и уравнения Кирхгофа для двух сетевых и двух компенсационных обмоток статора. Описывается последовательность решения уравнений и расчета векторного магнитного потенциала и рабочих характеристик двухфазного тихоходного компенсированного асинхронного двигателя.

Приводятся технические данные и результаты моделирования опытного образца двухфазного компенсированного асинхронного двигателя, на статоре которого размещается обмотка, ее токи возбуждают 10 пар полюсов. Анализ полученных результатов подтверждает возможность и целесообразность разработки и массового внедрения в нефтяной промышленности высокоэкономичных энергоэффективных двухфазных компенсированных тихоходных асинхронных двигателей.

Evgeniy F. Belyaev (Author ID in Scopus: 7006634296) - Doctor of Engineering, Professor at the Department of Electrical Engineering and Mechanics (tel.: +007342 237 84 51, e-mail: irina.shchapova@gmail.com).

Pavel N. Tsylev (Author ID in Scopus: 6504320743) - PhD in Engineering, Associate Professor at the Department of Mine Electrical Mechanics, Professor (tel.: +007 342219 84 21, e-mail: pcpn@pstu.ru).

Irina N. Shchapova (Author ID in Scopus: 55750286100) - PhD in Engineering, Associate Professor at the Department of Mine Electrical Mechanics (mob. tel.: +007 902 787 08 07, e-mail: irina.shchapova@gmail.com). The contact person.

Беляев Евгений Фролович - доктор технических наук, профессор кафедры электротехники и электромеханики (тел.: +007 342 237 84 51, e-mail: irina.shchapova@gmail.com). Цылев Павел Николаевич - кандидат технических наук, доцент кафедры горной электромеханики, професcop (тел.: +007 342 219 84 21, e-mail: pcpn@pstu.ru). Щапова Ирина Николаевна - кандидат технических наук, доцент кафедры горной электромеханики (моб. тел.: +007 9027870807 , e-mail: irina.shchapova@gmail.com). Контактное лицо для переписки. 


\section{Introduction}

Mechanical and electrical equipment that is used to lift oil to the surface is determined largely by flow rate of wells [1]. Wells with high and mean oil rates are operated by centrifugal pumps with electric drive from submersible induction motors. Frequency of rotation of a circular magnetic field of such engines, which is excited by currents of three-phase stator winding usually is $3000 \mathrm{~min}^{-1}$ [2]. The shaft torque of submerged induction motors, developed by electromagnetic forces, depends on the area of the outer surface of the electric motor rotor. Due to the small rotor diameter of submerged asynchronous motors, the torque required for operation of the centrifugal pump is provided by selection of appropriate rotor length and the motor as a whole.

Operation of low-productivity wells with rate of not more than $5 \mathrm{~m}^{3}$ per day is performed by rod pump systems (RPS). Reciprocating motion of a plunger of plunger pumps RPS in most of the cases is carried out using three-phase asynchronous electric motors with an higher starting torque or with higher slip [3, 4]. On a practical level, asynchronous electric motors with nominal power of $15,22,30 \mathrm{~kW}$ with rotational frequency of a stator magnetic field of $750,1000,1500 \mathrm{~min}^{-1}$ are most used [5]. $\mathrm{V}$-belt drive is used to transmit the torque from an electric motor shaft to a reductor input shaft. Depending on the diameter of a motor shaft pulley V-belt drive changes rotational speed in 2.86-4.5 times. In case reductor gear ratio is 40 then mentioned asynchronous motors ensure the operation of RPS with a number of double strokes of a plunger equal to 4-12.5 per minute. Having such frequency of double strokes of a plunder and low well production, periods when RPS are switched into operation alternate with periods of its shutdown, when liquid accumulates. Such mode of operation of RPS are called cyclic in technical literature and characterized by a number of significant drawbacks, which are indicated in works [6-8]. Transition to the most optimal "continuous" operation mode of RPS that lift liquid from wells with low production rate consider installation of asynchronous electric motors with rotational speed of a magnetic field of 375, 200, $150 \mathrm{~min}^{-1}$ at pumpjacks [9-11].

Among the primary problems that arise during the development of low-speed electromechanical energy converters, it is necessary to distinguish two such as need to reduce overall dimensions of engines and increase a values of their most important energy index which is power coefficient [12-14].

Let us focus on possible approaches to solve the problems mentioned above.

\section{New direction in improvement of RPS electric drive}

It is known from the theory of electric alternating current machines that the rotational speed of the stator magnetic field of the stator of asynchronous electric motors $n_{0}$, frequency of voltage in a supply network $f$ and a number of pole pairs of a stator winding $p$ are connected to each other by the equation [15-17]

$$
n_{0}=60 \mathrm{f} / \mathrm{p} \text {. }
$$

It is obvious that frequency of rotational speed of a circular magnetic field of the stator at $50 \mathrm{~Hz}$ of supply voltage is clearly determined by the number of pole pairs of its winding.

Dependence of rotational speed of a circular magnetic field on a number of pairs of poles of a stator winding

\begin{tabular}{|l|c|c|c|c|c|c|c|c|c|}
$p$, rel.units & 1 & 2 & 3 & 4 & 6 & 8 & 10 & 15 & 20 \\
\hline$m_{0}$ min $^{-1}$ & 3000 & 1500 & 1000 & 750 & 500 & 375 & 300 & 200 & 150 \\
\hline
\end{tabular}

\begin{tabular}{|l|l|l|l|l|l|l|l|l|l|}
\hline$n_{0}, \min ^{-1}$ & 3000 & 1500 & 1000 & 750 & 500 & 375 & 300 & 200 & 150 \\
\hline
\end{tabular}

According to the data presented, development of asynchronous electric motors with a magnetic field of rotation frequency of $300,200,150 \mathrm{~min}^{-1}$ considers the placement of the three-phase winding with a number of pairs of poles of 10, 15, 20 in stator grooves respectively.

The diameter of internal stator boring depends on a number of pairs of poles of the three-phase stator winding

$$
d_{\mathrm{s}}=2 p \tau / \pi
$$

where $\tau$ is for length of pole division. As a number of pairs of poles of the three-phase winding increases, a diameter of the stator inner boring and outer stator diameter increase. An outer rotor diameter increases as well. That diameter is less than a diameter of the inner stator boring by double amount of air gap accepted for small and medium power engines $0.35-0.70 \mathrm{~mm}$ [18]. Consequently, dimensions of a motor increase as a number of pairs of poles of the stator winding increases and rotation frequency of its magnetic field decreases. Increase in a rotor diameter, caused by increase in a number of pairs of poles of the stator winding, leads to increase in the flywheel moment of a rotor and negatively affects the speed of an engine and dynamics of a plunger motor drive. 
One of the solutions contributing to reduce in overall dimensions of asynchronous motors of an electric drive of the plunger RPS and increase in their speed is to place a two-phase winding in the stator grooves. Such a technical solution allows to reduce the length of the pole division of a stator winding in 1.5 times, which helps to reduce an inner stator diameter and outer rotor diameter.

However, until recently asynchronous electric motors with a two-phase winding on a stator have not been considered as an alternative to asynchronous electric motors with a three-phase winding. That was explained by poor performance characteristics of two-phase asynchronous motors and their more complicated design. The first disadvantage of asynchronous electric motors with a two-phase winding on a stator is caused by two factors such as ellipse shape of a magnetic field existing in an air gap and by using of a phaseshifting element in an engine design [19-21].

Development of the original design of a twophase asynchronous electric motor [22] changes the situation dramatically.

There are two equal groups of sections in the grooves of the steel laminated core of the stator of such a motor. Sections are made from isolated wire, usually copper. Sections of one group differ from sections of another group by a number of turns and wire cross-section. Stacking of sections of groups in grooves and their connection schemes in the formation of single-phase windings are carried out in a special way to ensure spatial shift of axes of windings by $90^{\circ}$. Outputs of singlephase winding formed by sections that have a smaller number of turns are connected to one of the phase voltages of a four-wire three-phase supply network. Outputs of a single-phase winding formed by sections with a large number of turns are connected to the phase-to-phase voltage of the supply network, which varies in time with a phase shift relative to the above mentioned phase voltage by $90^{\circ}$. Spatial shift of axes of single-phase windings by $90^{\circ}$ and time shift of the stress change curves by $90^{\circ}$ on the outputs of windings allow obtaining a circular magnetic field in a air gap of the engine. At that it is important to say that the circular shape of a magnetic field in a gap between a stator and rotor remains in the slip range from 1 to 0 . Performance characteristics calculated based on a mathematical model of such two-phase asynchronous motor are similar to characteristics of three-phase asynchronous motors [23].

The second significant drawback, common for slow-moving three-phase asynchronous electric motors, in particular low power coefficient, is not eliminated even in two-phase asynchronous engines of the described above design. The reason for such a drawback is that force lines of a magnetic field created by currents of a stator phases winding through each pair of poles cross twice an air gap that has a large magnetic resistance. To overcome the magnetic resistance of the air gap between the stator and rotor a significant magnetizing current is required. That comes from the expression [24]

$$
I_{\mu}=\frac{p F_{0}}{0,9 m w k_{0}}
$$

where $I_{\mu}$ is for the magnetizing current; $F_{0}$ is for the magnetic moving force per pair of poles; $m$ is for the number of motor phases; $w$ is for the number of turns in the phase winding; $k_{0}$ is for a winding coefficient. The negative effect of the magnetizing current on the power coefficient is particularly large in electromechanical low-power energy converters. Those converters are required for driving of the RPS plunger that lift liquid from wells with low production rate. For example, low-speed $\left(n_{0}=375 \mathrm{~min}^{-1}\right)$ asynchronous motors of $4.5 \mathrm{~kW}$ of power, designed to drive the plunger of RPS and produced by OOO "Vladimirskiy elektromotornyy zavod" have the power coefficient of 0.46 [25].

Unsatisfactory values of the power coefficient and as a result low energy efficiency of low-speed asynchronous engines negatively affect the growth of the load of current-carrying elements of power supply systems and are constraining factors for their mass serial production.

Internal compensation of magnetizing currents of the stator windings is a new direction that contribute to improvment of the energy efficiency of slow-moving two-phase asynchronous motors. For that, two single-phase compensation windings in addition to two single-phase network windings are placed in grooves of the stator steel core. Outputs of compensation windings are connected to capacitors. To carry out the operation of such a motor, the network windings are connected to a three-phase alternating voltage network. A circular magnetic field, which in this case is created by the currents of these windings, induces electromotive forces in the compensating windings. Under the action of those electromotive forces en electric current is flowing along the compensating windings that has an advanced current. As a consequence, total magnetomotive force and electromotive force of the network windings increase. That causes a decrease in magnetizing currents of the network windings. Such a process continues until the electromotive 
forces of the network windings together with the voltage drops at their resistances reach the values of the voltages that act on winding terminals.

\section{Mathematical model of a two-phase compensated asynchronous motor of electrical drive of the plunger of RPS}

In order to test work reliability of a two-phase compensated asynchronous motor a mathematical model is used [26, 27]. The equation of the magnetic field $[28,29]$ and Kirchhoff's equations $[30,31]$ are used as a basis for a mathematical model performance. The number of equations equals to the number of one-phase windings placed in the grooves of a stator.

The equation of the magnetic field of an asynchronous motor with a rotor winding of the "squirrel cage" type is as follows

$$
\begin{gathered}
\frac{1}{R_{0}^{2}} \frac{\partial^{2} A}{\partial \varphi^{2}}-\mu_{0} \gamma\left(1+k_{\sigma 2}\right) \omega \frac{\partial A}{\partial \varphi}- \\
-\mu_{0} \gamma\left(1+k_{\sigma 2}\right) \omega \frac{\partial A}{\partial t}-q A=-\mu_{0} J_{\mathrm{s}},
\end{gathered}
$$

where $A$ is for vector potential of a magnetic field ( $z$ is for constituent); $R_{0}$ is for mean radius of an air gap; $\varphi$ is for tangential coordinate of the cylindrical coordinate system; $\mu_{0}$ is for magnetic constant; $\gamma$ is for Calculated conductivity of the conductors of the "squirrel cage" of the rotor, distributed in the motor gap; $k_{\sigma 2}$ is for a coefficient of rotor scattering grooves; $\omega$ is for angular rotational speed of a rotor; $q$ is for coefficient that considers magnetic resistance of the motor magnetic circuit segments.

A boundary value problem described by equation (4) is solved taking into account boundary conditions of periodic type, expressing the equality of vector potentials and their derivatives at a conjugate point.

In case of sinusoidal nature of change of calculated quantities in time a solution of the problem can be simplified by shift to complex functions. In this case the differential equation (4) reduces to

$$
\begin{gathered}
\frac{1}{R_{0}^{2}} \frac{\partial^{2} \dot{A}}{\partial \varphi^{2}}-\mu_{0} \gamma\left(1+k_{\sigma 2}\right) \omega \frac{\partial \dot{A}}{\partial \varphi}- \\
-\left(j \omega \mu_{0} \gamma\left(1+k_{\sigma 2}\right)+q\right) \dot{A}=-\mu_{0} \dot{J}_{\mathrm{s}},
\end{gathered}
$$

where $\dot{A}$ is for a vector potential complex; $j$ is for the imaginary unit; $\dot{J}_{\mathrm{s}}$ is for the stator current load complex.
The system of Kirchhoff equations compiled for the network and compensating stator windings is written as follows:

$$
\begin{gathered}
\dot{U}_{A}=j \omega \dot{\Psi}_{A}+\dot{I}_{A}\left(Z_{A}+j X_{2 S A}\right), \\
\dot{U}_{B}=j \omega \dot{\Psi}_{B}+\dot{I}_{B}\left(Z_{B}+j X_{2 S B}\right), \\
0=j \omega \dot{\Psi}_{A K}+\dot{I}_{A K}\left(Z_{A K}+j X_{2 S A K}-j X_{C A}\right), \\
0=j \omega \dot{\Psi}_{B K}+\dot{I}_{B K}\left(Z_{B K}+j X_{2 S B K}-j X_{C B}\right) .
\end{gathered}
$$

Equations (6)-(9) are written using complex quantities. Notation assumed is as follows: $\dot{U}_{A}, \dot{U}_{B}$ are for phase and linear voltage; $\dot{\Psi}$ is for linkage; $\dot{I}$ is for current; $Z$ is for full resistance; $X_{2 S}$ is for reduced induction resistance of a rotor; $X_{C}$ is for capacitive resistance. Indexes $A, B, A K, B K$ mean the belonging of this parameter to the corresponding network or compensation winding.

The linkages of the network and compensating windings of a two-phase asynchronous motor are caused by currents passing through the windings and are calculated by expressions

$$
\begin{aligned}
& \dot{\Psi}_{A}=L_{11} \dot{I}_{A}+L_{12} \dot{I}_{B}+L_{13} \dot{I}_{A K}+L_{14} \dot{I}_{B K}, \\
& \dot{\Psi}_{B}=L_{21} \dot{I}_{A}+L_{22} \dot{I}_{B}+L_{23} \dot{I}_{A K}+L_{24} \dot{I}_{B K}, \\
& \dot{\Psi}_{A K}=L_{31} \dot{I}_{A}+L_{32} \dot{I}_{B}+L_{33} \dot{I}_{A K}+L_{34} \dot{I}_{B K}, \\
& \dot{\Psi}_{B K}=L_{41} \dot{I}_{A}+L_{42} \dot{I}_{B}+L_{43} \dot{I}_{A K}+L_{44} \dot{I}_{B K} .
\end{aligned}
$$

The right-hand sides of equations (10)-(13) contain complex self-induction coefficients (L with two identical indexes) and mutual inductance ( $L$ with two different indexes).

After substituting of (10)-(13) into Kirchhoff's equations (6)-(9) and performing the corresponding transformations a system of four equations where four currents are unknown such as two currents of the network windings and two currents of compensating windings:

$$
\begin{gathered}
\dot{U}_{A}=\left(j \omega_{0} L_{11}+Z_{A}+j X_{2 S A}\right) \dot{I}_{A}+ \\
+j \omega_{0} L_{12} \dot{I}_{B}+j \omega_{0} L_{13} \dot{I}_{A K}+j \omega_{0} L_{14} \dot{I}_{B K}, \\
\dot{U}_{B}=j \omega_{0} L_{21} \dot{I}_{A}+\left(j \omega_{0} L_{22}+Z_{B}+j X_{2 S B}\right) \dot{I}_{B}+ \\
+j \omega_{0} L_{23} \dot{I}_{A K}+j \omega_{0} L_{24} \dot{I}_{B K}, \\
0=j \omega_{0} L_{31} \dot{I}_{A}+j \omega_{0} L_{32} \dot{I}_{B}+ \\
+\left(j \omega_{0} L_{33}+Z_{A K}+j X_{2 S A}-j X_{C A}\right) \dot{I}_{A K}+ \\
+j \omega_{0} L_{34} \dot{I}_{B K},
\end{gathered}
$$




$$
\begin{gathered}
0=j \omega_{0} L_{41} \dot{I}_{A}+j \omega_{0} L_{42} \dot{I}_{B}+j \omega_{0} L_{43} \dot{I}_{A K}+ \\
+\left(j \omega_{0} L_{44}+Z_{B K}+j X_{2 S B}-j X_{C B}\right) \dot{I}_{B K} .
\end{gathered}
$$

In order to solve the system of equations (14)(17) and calculate the values of the currents in the network and compensating windings, it is necessary to know the coefficients of selfinduction and mutual induction. It is expedient to calculate these coefficients using the superposition method in a sequence given below.

A value of one of the currents at zero values of the other three currents is assumed. The equation of the magnetic field (5) is solved. As a result, the magnitude of the vector potential at the points of the spatial coordinate $\varphi$ division is determined. The points correspond to the location of the conductors of the stator windings. It is assumed that all the conductors placed in the stator groove transmit the same magnitude current. Linkages of the coils are calculated by integrating the vector potential values at the locations of the conductors of each of the windings:

$$
\Psi_{K}=w_{K}\left(A_{H}-A_{K}\right) l_{\delta},
$$

where $w_{K}$ is for a number of turns in the coil; $A_{H}$, $A_{K}$ are for values of the vector potential at points whose coordinates correspond to the coordinates of coil sides; $l_{\delta}$ is for length of the active part of the conductor (i.e. part of the coil) placed in the groove of the stator. Determination of linkages of the windings $\Psi_{A}, \Psi_{B}, \Psi_{A K}, \Psi_{B K}$ is performed by summation of linkages of coils that belong to the network and compensation windings of the stator. Then coefficients of self and mutual induction are calculated

$$
\begin{gathered}
L_{11}=\frac{\dot{\Psi}_{A}}{\dot{I}_{A}}, L_{21}=\frac{\dot{\Psi}_{B}}{\dot{I}_{A}}, \\
L_{31}=\frac{\dot{\Psi}_{A K}}{\dot{I}_{A}}, L_{41}=\frac{\dot{\Psi}_{B K}}{\dot{I}_{A}} .
\end{gathered}
$$

Values of self and mutual induction coefficients of the second network winding and compensating stator windings that are included in the equations (14)-(17) and still left unknown are calculated by performing similar procedures.

If coefficients of self and mutual induction and specified capacitance values of the capacitors included in the compensation winding circuit are known then the system of equations (14)-(17) is solved and currents in network and compensation windings are determined.

Power $P$ consumed by a motor from the electric mains, electromagnetic power $P_{\text {e.p }}$, effective shaft power $P_{2}$, lectromagnetic moment $M_{\text {e.m }}$, power coefficient $\cos \varphi$, efficiency factor $\eta$ are calculated using known expressions:

$$
\begin{gathered}
P=\operatorname{Re}\left(\dot{U}_{A} \vec{I}_{A}+\dot{U}_{B} \bar{I}_{B}\right), \\
P_{\text {e.p }}=P-R_{A} I_{A}^{2}-R_{B} I_{B}^{2}, \\
P_{2}=P(1-s), \\
M_{\text {e.p }}=\frac{P_{\text {e.p }}}{\omega}, \\
\cos \varphi=\frac{P}{U_{A} I_{A}+U_{B} I_{B}}, \\
\eta=\frac{P_{2}}{P},
\end{gathered}
$$

where Re is for a symbol of a real part of a complex number; $\bar{I}_{A}, \bar{I}_{B}$ are for complexes of acting current values conjugated with sets of acting values of currents of network windings; $R_{A}, R_{B}$ are for active resistances of network windings; $s$ is for slip; $\omega$ is for circular frequency;

$$
\omega=\omega_{0} \frac{1-s}{p} .
$$

An asynchronous motor was used as a model of a low-speed two-phase asynchronous electromechanical energy converter. An asynchronous motor has the following parameters:

- number of pairs of poles $p-10$;

- bore diameter of stator $d_{c}-383 \mathrm{~mm}$;

- air gap between stator and rotor $\delta-0.554 \mathrm{~mm}$;

- stator length in axial direction $l_{a}-200 \mathrm{~mm}$;

- number of turns $w_{A}$ of the network winding of a " $A-X$ " phase -80 ;

- number of turns $w_{B}$ of the network winding of a " $B-Y$ " phase - 139 ;

- number of turns $w_{A K}$ of the phase compensation winding of a " $A-X$ " -35 ;

- number of turns $w_{B K}$ of the phase compensation winding of a " $B-Y$ " phase -35 ;

- calculated electrical conductivity of the rotor cell material $\gamma-190 \cdot 10^{6} \mathrm{Sm}$;

- coefficient $q-1320$;

- active resistance of the network winding of a " $A$ - $X$ " phase $-0.36 \mathrm{Ohm}$;

- inductive resistance of the network winding of a " $A$ - $X$ " phase $-0.756 \mathrm{Ohm}$;

- active resistance of the network winding of a " $B-Y$ " phase $-1.08 \mathrm{Ohm;}$

- inductive resistance of the network winding of a " $B-Y$ " phase $-2.268 \mathrm{Ohm}$;

- active resistance of the compensation winding of a " $A$ - $X$ " phase $-0.02225 \mathrm{Ohm}$; 
- inductive resistance of the compensation winding of a " $A$ - $X$ " phase $-0.04725 \mathrm{Ohm}$;

- active resistance of the compensation winding of a " $B-Y$ " phase $-0.02225 \mathrm{Ohm}$;

- inductive resistance of the compensation winding of a " $B-Y$ " phase $-0.04725 \mathrm{Ohm}$;

- inductive resistance of the rotor winding, reduced to the parameters of the winding of a " $A$ - $X$ " phase $-1.37 \mathrm{Ohm \text {; }}$

- inductive resistance of the rotor winding, reduced to the parameters of the network winding of a " $B-Y$ " phase $-4.11 \mathrm{Ohm}$;

- inductive resistance of the rotor winding, reduced to the parameters of the compensation winding of a " $A$ - $X$ " phase $-0.0856 \mathrm{Ohm}$;

- inductive resistance of the rotor winding, reduced to the parameters of the compensation winding of a " $B-Y$ " phase $-0.0856 \mathrm{Ohm}$;

- capacitance in the compensating winding circuit of a " $A$ - $X$ " phase $-900 \mu \mathrm{F}$;

- capacitance in the compensating winding circuit of a " $B$ - $Y$ " phase $-900 \mu \mathrm{F}$;

- voltage complex on the phase network winding of a " $A-X$ " $-219.4 \mathrm{~V}$;

- voltage complex on the network winding of a " $B-Y$ " phase $-j 380 \mathrm{~V}$.

Modelling of the operating mode of an uncompensated two-phase asynchronous motor and two-phase asynchronous motor in which the magnetizing current and reactive power are compensated is done under the conditions where the slip value $s$ is 0.05 . Some modelling results of the mentioned two-phase asynchronous motors are given below as a matrix of coefficients of self and mutual induction and the values of a number of their most important performance indicators (Table). Modelling results are shown in the vector diagrams as well (Fig. 1, 2). The diagrams include stress vectors on the stator network windings and vectors of their magnetomotive forces.

Matrix of coefficients of self and mutual induction of inductance $L$

$0.0148-0.0163 j ; 0.0256+0.0253 j ; 0.0064-$ $-0.0071 j ; 0.0064+0.0063 j$;

$-0.0256-0.0253 j ; 0.0443-0.4890 j ;-0.0111-$

$-0.011 j ; 0.0111-0.0122 j$;

$0.0064-0.0063 j ; 0.0111+0.0110 j ; 0.0028-$

$-0.0031 j ; 0.0028+0.0027 j$;

$-0.0064-0.0063 j ; 0.0111-0.0122 j ;-0.0028-$

$-0.0027 j ; 0.0028-0.00310 j$.
Table

Values of a number of basic performance parameters of a two-phase asynchronous motor

\begin{tabular}{|l|c|c|}
\hline \multicolumn{1}{|c|}{ Name of the parameter } & $\begin{array}{c}\text { No } \\
\text { compensation }\end{array}$ & $\begin{array}{c}\text { Compen- } \\
\text { sation }\end{array}$ \\
\hline $\begin{array}{l}\text { Current in the network winding of a } \\
\text { " } A-X \text { " phase, A }\end{array}$ & 14.63 & 11.95 \\
\hline $\begin{array}{l}\text { Current in the network winding of a } \\
\text { " } B \text { - } Y \text { " phase, A }\end{array}$ & 8.45 & 6.90 \\
\hline $\begin{array}{l}\text { Current in the compensation winding } \\
\text { of a " } A-X \text { " phase, A }\end{array}$ & 0 & 27.86 \\
\hline $\begin{array}{l}\text { Current in the compensation winding } \\
\text { of a " } B-Y \text { " phase, A }\end{array}$ & 0 & 27.86 \\
\hline Electromagnetic power, W & 4120.1 & 5137.7 \\
\hline Electromagnetic moment, N·m & 131.15 & 163.54 \\
\hline Efficiency factor, rel. units & 0.61 & 0.93 \\
\hline Power coefficient, rel. units & 0.64 & 0.98 \\
\hline
\end{tabular}

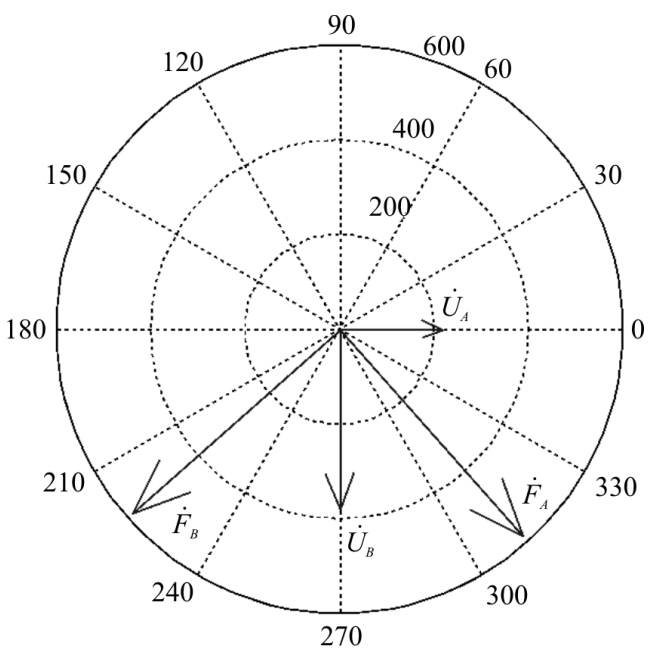

Fig. 1. Vector diagram of stresses and magnetomotive forces of a single-phase asynchronous motor with no compensation

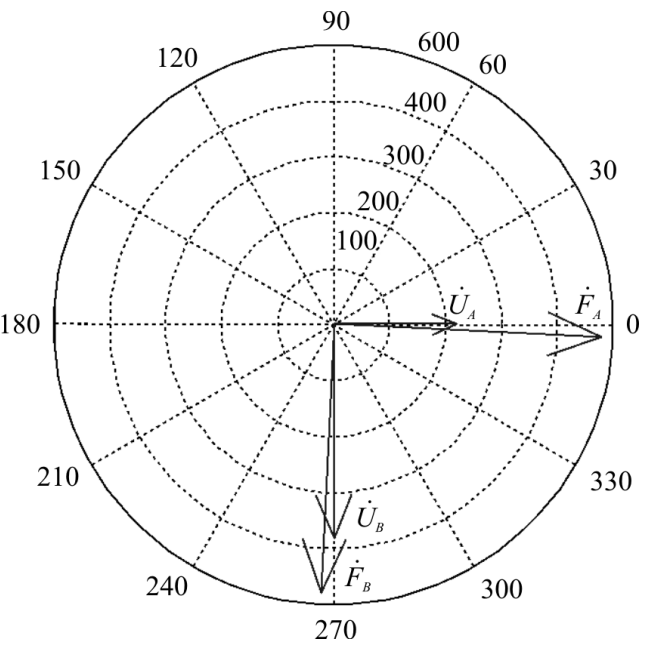

Fig. 2. Vector diagram of stresses and magnetomotive forces of a single-phase compensated asynchronous motor 
Analysis of modelling results clearly shows that the values of the coefficients of self and mutual induction are invariant with respect to the current of the compensation windings. The higher the compensation the lower the currents in the network windings. There is an increase in the electromagnetic power and the electromagnetic moment. Energy parameters and energy efficiency of the motor increase significantly. Increase in energy parameters and decrease in currents, consumed from the electrical mains of the three-phase alternating voltage, contribute to reduction the current load of current carrying elements of the power supply systems. That creates a reserve for connecting of additional electric loads to existing electric networks. The above mentioned is illustrated by the vector diagrams shown in Fig. 1, 2.

It is clearly seen that there is a significant angle in a two-phase asynchronous motor with a network of winds on the stator between the voltage vectors on the network of windings and the vectors of the magnetomotive forces. There is a significat magnetizing component in the currents of the network windings that causes the consumption of reactive power from the supply network. Stacking of compensation windings in stator grooves and their connection to capacitors allow to eliminate a magnetizing component in the currents of the network windings. Angles of the phase shift between voltage vectors at the terminals of network windings and vectors of magnetomotive forces are in this case close to zero. A motor consumes only the active power from the $\mathrm{AC}$ electrical mains supply.

\section{Conclusion}

Studies of performance of a two-phase asynchronous compensated motor on a mathematical model allow asserting that the results obtained and conclusions remain valid for the slip range from 1 to 0 . Production and wide implementation of two-phase asynchronous compensated motors in the plunger drive of RPS allow switching the operation regime of low productive oil wells to the most rational, increase the energy efficiency of the oil production and save energy resources.

\section{References}

1. Galkin V.I., Galkin S.V., Voevodkin V.L., Permiakov V.G. Postroenie statisticheskikh modelei otsenki koeffitsienta izvlecheniia nefti dlia ekspluatatsionnykh ob"ektov Permskogo Prikam'ia [Construction of statistical models for estimating the oil recovery factor for operational facilities of Perm Kama Region]. Neftianoe khoziaistvo, 2011, no.2, pp.86-88.

2. Spravochnaia kniga po dobyche nefti [Reference book on oil production]. Ed. Sh.K. Gimatudinov. Moscow, Nedra, 1974, 704 p.

3. Spravochnik po elektricheskim mashinam [Reference book of electrical machines]. Ed. I.P. Kopylov, B.K. Klokov. Moscow, Energoatomizdat, 1988, vol.1, 456 p.

4. Alves M.F., Burke P.E. Single-sided linear induction motor with magnetic material in the secondary. Conference Record of the IEEE Industry Applications Conference 1973, Eighth Annual Meeting. Milwaukee, 1973, pp.321-329.

5. Arkhangel'skii V.L. et al. Katalog neftianogo oborudovaniia, sredstv avtomatizatsii, priborov i spetsmaterialov [Catalog of oil equipment, automation, instruments and special materials]. Moscow, VNIIOENG, 1994, vol.2, $216 \mathrm{p}$.

6. Neftegazovoe delo. Vol. 3: Dobycha nefti i gaza [Oil and gas business. Vol. 3: Oil and gas production]. Ed. Iu.V. Zeigman. Saint Petersburg, Nedra, 2011, 285 p.

7. Mishchenko I.T. Skvazhinnaia dobycha nefti [Downhole oil production]. Moscow, Neft' i gaz, 2003, $816 \mathrm{p}$.

8. Tsylev P.N., Shchapova I.N. Alternatives to improve capacity coefficient of induction motors for oil-gas industry. Bulletin of Perm National Research Polytechnic University.
Geology. Oil \& Gas Engineering \& Mining, 2015, no.16, pp.77-85. DOI: 10.15593/2224-9923/2015.16.9

9. Tsylev P.N., Shchapova I.N., Shchapov V.A. Povyshenie energoeffektivnosti asinkhronnykh elektromekhanicheskikh preobrazovatelei energii elektroprivoda skvazhinnykh shtangovykh nasosov [Direction to increase the energy efficiency of asynchronous electromechanical energy converters for electric drive of sucker rod pumping installations]. Neftianoe khoziaistvo, 2014, no.5, pp.110-113.

10. Charonov V.Ia. Ekonomichnye elektroprivody dlia stankov-kachalok malodebitnykh skvazhin [Economical electric drives for rocking machines of low-yield wells]. Neftianoe khoziaistvo, 1996, no.12, pp.46-48.

11. Retter G.J. The dyadic analysis of partially asymmetrical machines. Archiv für Elektrotechnik, 1978, vol.60, iss. 2, pp.69-78. DOI: 10.1007/BF01578628

12. Tsylev P.N., Shchapova I.N. Vysokoeffektivnye tikhokhodnye asinkhronnye preobrazovateli energii maloi moshchnosti dlia neftianoi promyshlennosti [Low-speed high efficiency asynchronous energy converters of low power for the oil industry]. Neftianoe khoziaistvo, 2013, no.4, pp.62-65.

13. Page C.H. Reactive power in nonsinusoidal situations. IEEE Transactions on Instrumentation and Measurement, 1980, vol. 29, iss. 4, pp.420-423. DOI: 10.1109/TIM.1980.4314971

14. Nabae A., Yoshikawa A., Cao L., Tanaka T. A new definition of instantaneous active-reactive current and power in three-phase circuits, and its application. Electrical Engineering in Japan (English translation of Denki Gakkai Ronbunshi), 1997, vol.121, iss.2, pp.83-91. 
15. Kisarimov R.A. Spravochnik elektrika [Directory of the electrician]. Moscow, Radiosoft, 2010, $512 \mathrm{p}$.

16. Eldhemy S.A. Theory of zero-sequence performance in induction machines without/with multiple armature reaction. Electric Machines and Power Systems, 1989, vol. 17, no.4-5, pp.295-313. DOI: 10.1080/07313568908909434

17. Vaske P. Über die drehfelder und drehmomente symmetrischer komponenten in induktionsmaschinen. Archiv für Elektrotechnik, 1963, vol.48, iss.2, pp.97-117. DOI: 10.1007/BF01419338

18. Ermolin N.P. Elektricheskie mashiny [Electric machines]. Moscow, Vysshaia shkola, 1975, 295 p.

19. Vol'dek A.I. Elektricheskie mashiny [Electric machines]. Leningrad, Energiia, 1974, 839 p.

20. Kopylov I.P. Elektricheskie mashiny [Electric machines]. Moscow, Energoatomizdat, 1986, 360 p.

21. Katsman M.M. Elektricheskie mashiny avtomaticheskikh sistem [Electric machines of automatic systems]. Ed. F.M. Iuferov. Moscow, Vysshaia shkola, 1979, 261 p.

22. Beliaev E.F., Tsylev P.N., Vlasov E.A. Tikhokhodnyi asinkhronnyi preobrazovatel' energii [Lowspeed asynchronous power converter]. Patent 2402141 Russian Federation, no.2009141468/07.

23. Beliaev E.F., Vlasov E.A., Ogarkov E.M., Tsylev P.N. Povyshenie effektivnosti dobychi nefti iz nizkodebitnykh skvazhin za schet sovershenstvovaniia elektrooborudovaniia stankov-kachalok [Increasing the efficiency of oil production from low-yield wells by improving the electrical equipment of rocking machines]. Neftepromyslovoe delo, 2010, no.7, pp.66-70.

24. Sergeev P.S., Vinogradov N.V., Goreinov F.A. Proektirovanie elektricheskikh mashin [Design of electrical machines]. Moscow, Energiia, 1970, 632 p.
25. Tekhnicheskii katalog elektrodvigatelei VEMZ, 2010, available at: http:/www.vemp.ru/prod/motors.html (accessed 26 March 2014).

26. Beliaev E.F., Shulakov N.V. Diskretno-polevye modeli elektricheskikh mashin [Discrete field models of electrical machines]. Perm', Izdatel'stvo Permskogo gosudarstvennogo tekhnicheskogo universiteta, 2009, part I, II. $457 \mathrm{p}$.

27. Petrov L.P. Die modelierung der energieverluste in asynchronmotoren unter beachtung der elektromagnetischen ubergangsprozesse. Elektrie, 1980, vol.34, no.7, pp.375-379.

28. Neiman L.R., Kalantarov P.L. Teoreticheskie osnovy elektrotekhniki. Part 3: Teoriia elektromagnitnogo polia [Theoretical bases of electrical engineering. Part 3: Theory of the electromagnetic field]. Moscow, Leningrad, Gosenergoizdat, 1959, $232 \mathrm{p}$.

29. Vas P. Modified symmetrical components theory and its application in the theory of asymmetrical induction motors. Periodica Polytechnica, Electrical Engineering, 1978, vol.22, iss.1, pp.3-12.

30. Neiman L.R., Kalantarov P.L. Teoreticheskie osnovy elektrotekhniki. Part 1: Fizicheskie osnovy elektrotekhniki i teoriia tsepei postoiannogo toka [Theoretical bases of electrical engineering. Part 1: Physical fundamentals of electrical engineering and the theory of DC circuits]. Moscow, Leningrad, Gosenergoizdat, 1959, $296 \mathrm{p}$.

31. Ching-Yin Lee, Wei- Yin Lee. Effects of nonsinusoidal voltage on the operation performance of a three-phase induction motor. IEEE Transactions on Energy Conversion, 1999, vol.14, no.2, pp.193-201. DOI: $10.1109 / 60.766983$

\section{Библиографический список}

1. Построение статистических моделей оценки коэффициента извлечения нефти для эксплуатационных объектов Пермского Прикамья / В.И. Галкин, С.В. Галкин, В.Л. Воеводкин, В.Г. Пермяков // Нефтяное хозяйство. -2011 . - № 2. - С. 86-88.

2. Справочная книга по добыче нефти / под. ред. Ш.К. Гиматудинова. - М.: Недра, 1974. - 704 с.

3. Справочник по электрическим машинам: в 2 т. / под общ. ред. И.П. Копылова, Б.К. Клокова. - М.: Энергоатомиздат, 1988. - Т. 1. -456 с.

4. Alves M.F., Burke P.E. Single-sided linear induction motor with magnetic material in the secondary // Conference Record of the IEEE Industry Applications Conference 1973, Eighth Annual Meeting. - Milwaukee, 1973. - P. 321-329.

5. Каталог нефтяного оборудования, средств автоматизации, приборов и спецматериалов / В.Л. Архангельский [и др.]. - М.: ВНИИОЭНГ, 1994.- Т. 2. - 216 с.

6. Нефтегазовое дело: учеб. пособие: в 6 т. / под ред. А.М. Шаммазова. Т. 3. Добыча нефти и газа / под ред. Ю.В. Зейгмана. - СПб.: Недра, 2011. - 285 с.

7. Мищенко И.Т. Скважинная добыча нефти: учеб. пособие для вузов. - М.: Нефть и газ, 2003. - 816 с.

8. Цылев П.Н., Щапова И.Н. Направления повышения коэффициента мощности асинхронных электроприводов механизмов предприятий нефтяной отрасли // Вестник Пермского национального исследовательского политехнического университета. Геология. Нефтегазовое и горное дело. - 2015. № 16. - C. 77-85. DOI: 10.15593/2224-9923/2015.16.9

9. Цылев П.Н., Щапова И.Н., Щапов В.А. Повышение энергоэффективности асинхронных электромеханических преобразователей энергии электропривода скважинных штанговых насосов // Нефтяное хозяйство. - 2014. - № 5. - С. 110-113.

10. Чаронов В.Я. Экономичные электроприводы для станков-качалок малодебитных скважин // Нефтяное хозяйство. - 1996. - № 12. - С. 46-48.

11. Retter G.J. The dyadic analysis of partially asymmetrical machines // Archiv für Elektrotechnik. - 1978. - Vol. 60, iss. 2. - P. 69-78. DOI: 10.1007/BF01578628

12. Цылев П.Н., Щапова И.Н. Высокоэффективные тихоходные асинхронные преобразователи энергии малой мощности для нефтяной промышленности // Нефтяное хозяйство. - 2013. - № 4. - С. 62-65.

13. Page C.H. Reactive power in nonsinusoidal situations // IEEE Transactions on Instrumentation and Measurement. - 1980. - Vol. 29, iss. 4. - P. 420-423. DOI: 10.1109/TIM.1980.4314971

14. A new definition of instantaneous active-reactive current and power in three-phase circuits, and its application / A. Nabae, A. Yoshikawa, L. Cao, T. Tanaka // Electrical Engineering in Japan (English translation of Denki Gakkai Ronbunshi). - 1997. - Vol. 121, iss. 2. - P. 83-91. 
15. Кисаримов Р.А. Справочник электрика. 4-е изд., исправл. и доп. - М.: Радиософт, 2010. - 512 с.

16. Eldhemy S.A. Theory of zero-sequence performance in induction machines without/with multiple armature reaction // Electric Machines and Power Systems. - 1989. - Vol. 17, № 4-5. - P. 295-313. DOI: 10.1080/07313568908909434

17. Vaske P. Über die Drehfelder und Drehmomente symmetrischer Komponenten in Induktionsmaschinen // Archiv für Elektrotechnik. - 1963. - Vol. 48, iss. 2. P. 97-117. DOI: 10.1007/BF01419338

18. Ермолин Н.П. Электрические машины: учеб. для втузов. - М.: Высшая школа, 1975. - 295 с.

19. Вольдек А.И. Электрические машины. 2-е изд., перераб. и доп. - Л.: Энергия, 1974. - 839 с.

20. Копылов И.П. Электрические машины. - М.: Энергоатомиздат, 1986. - 360 с.

21. Кацман М.M. Электрические машины автоматических систем: учеб. для электроприборостроит. спец. техникумов / под ред. Ф.М. Юферова. - 2-е изд., перераб. и доп. - М.: Высшая школа, 1979. - 261 с.

22. Тихоходный асинхронный преобразователь энергии: пат. 2402141 Рос. Федерация / Беляев Е.Ф., Цылев П.Н., Власов Е.А. - № 2009141468/07; заявл. 09.11.09; опубл. 20.10.10, Бюл. № 29. - 9 с.

23. Повышение эффективности добычи нефти из низкодебитных скважин за счет совершенствования электрооборудования станков-качалок / Е.Ф. Беляев, Е.А. Власов, Е.М. Огарков, П.Н. Цылев // Нефтепромысловое дело. - 2010. - № 7. - С. 66-70

24. Сергеев П.С., Виноградов Н.В., Гореинов Ф.А. Проектирование электрических машин. - М.: Энергия, 1970. -632 c.
25. Технический каталог электродвигателей ВЭМЗ $(2010$ г.) [Электронный peсурс]. - URL: http://www.vemp.ru/ prod/motors.html (дата обращения: 26.03.2014).

26. Беляев Е.Ф., Шулаков Н.В. Дискретно-полевые модели электрических машин: учеб. пособие. Пермь: Изд-во Перм. гос. техн. ун-та, 2009. - Ч. I, II. $457 \mathrm{c}$

27. Petrov L.P. Die Modelierung der energieverluste in asynchronmotoren unter beachtung der elektromagnetischen ubergangsprozesse // Elektrie. - 1980. - Vol. 34, № 7. S. 375-379.

28. Нейман Л.Р., Калантаров П.Л. Теоретические основы электротехники: учебник для электротехн. и энергет. вузов и факультетов: в 3 ч. Ч. 3. Теория электромагнитного поля. - М.; Л.: Госэнергоиздат, 1959. $-232 \mathrm{c}$

29. Vas P. Modified symmetrical components theory and its application in the theory of asymmetrical induction motors // Periodica Polytechnica, Electrical Engineering. 1978. - Vol. 22, iss. 1. - P. 3-12.

30. Нейман Л.Р., Калантаров П.Л. Теоретические основы электротехники: учебник для электротехн. и энергет. вузов и факультетов: в 3 ч. Ч. 1. Физические основы электротехники и теория цепей постоянного тока. - М.; Л.: Госэнергоиздат, 1959. - 296 c

31. Ching-Yin Lee, Wei-Yin Lee. Effects of nonsinusoidal voltage on the operation performance of a three-phase induction motor // IEEE Transactions on Energy Conversion. - 1999. - Vol. 14, № 2. - P. 193-201. DOI: $10.1109 / 60.766983$

Please cite this article in English as:

Belyaev E.F., Tsylev P.N., Shchapova I.N. Biphase multi-pole compensated asynchronous motor for oil industry. Perm Journal of Petroleum and Mining Engineering, 2017, vol.16, no.3, pp.238-246. DOI: 10.15593/2224-9923/2017.3.4

Просьба ссылаться на эту статью в русскоязычных источниках следующим образом:

Беляев Е.Ф., Цылев П.Н., Щапова И.Н. Двухфазный многополюсный компенсированный асинхронный двигатель для нефтяной промышленности // Вестник Пермского национального исследовательского политехнического университета. Геология. Нефтегазовое и горное дело. - 2017. - Т.16, №3. - C.238-246. DOI: 10.15593/2224-9923/2017.3.4 